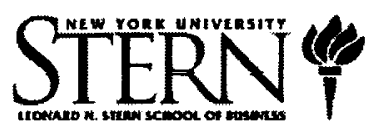

\begin{abstract}
NEW YORK UNIVERSITY
STERN SCHOOL OF BUSINESS

FINANCE DEPARTMENT
\end{abstract}

Working Paper Series, 1996

Managerial Entrenchment and Capital Structure Decisions

Berger, Philip E., Eli Ofek and David Yermack

FIN-96-14 


\title{
Managerial Entrenchment and Capital Structure Decisions
}

\author{
Philip G. Berger \\ Wharton School, University of Pennsylvania \\ 2433 Steinberg-Dietrich Hall, Philadelphia, PA 19104-6365 \\ Phone: (215) 898-7125 Fax: (215) 573-2054 \\ Eli Ofek \\ Stern School of Business, New York University \\ 44 West 4th St., Suite 9-190, New York, NY 10012-1126 \\ Phone: (212) 998-0356 Fax: (212) 995-4233 \\ David L. Yermack \\ Stern School of Business, New York University \\ 44 West 4th St., Suite 9-160, New York, NY 10012-1126 \\ Phone: (212) 998-0357 Fax: (212) 995-4233
}

December 1996

The authors appreciate helpful comments from René Stulz (the editor), two anonymous referees, and seminar participants from Boston College, Columbia University, and New York University. Berger acknowledges the financial support of Coopers \& Lybrand. 


\title{
Managerial Entrenchment and Capital Structure Decisions
}

\begin{abstract}
We study associations between managerial entrenchment and firms' capital structures, with results generally suggesting that entrenched CEOs seek to avoid debt. In a cross-sectional analysis, we find that leverage levels are lower when CEOs do not face pressure from either ownership and compensation incentives or active monitoring. In an analysis of leverage changes, we find that leverage increases in the aftermath of entrenchment-reducing shocks to managerial security, including unsuccessful tender offers, involuntary CEO replacements, and the addition to the board of major stockholders.
\end{abstract}


Much capital structure research follows Jensen and Meckling (1976) in using agency theory to argue that managers do not always adopt capital structures with the value-maximizing level of debt. Some managers appear to entrench themselves considerably against pressures from internal and external corporate governance mechanisms, and our paper tests whether the degree of this entrenchment impacts firms' choices about capital structure. We find empirical support for this theory in a panel of 434 firms studied between 1984 and 1991.

We define entrenchment as the extent to which managers fail to experience discipline from the full range of corporate governance and control mechanisms, including monitoring by the board, the threat of dismissal or takeover, and stock- or compensation-based performance incentives. Entrenched managers by definition have discretion over their firms' leverage choices. Managers may prefer less leverage than optimal because of a desire to reduce firm risk to protect their underdiversified human capital (e.g., Fama (1980)) or their dislike of performance pressures associated with commitments to disgorge large amounts of cash (e.g., Jensen (1986)).' Conversely, Harris and Raviv (1988), Stulz (1988) and others suggest that entrenchment motives may cause

1 Jensen's (1986) view that high debt levels constrain managers from diverting "free" cash flow to pursue personal goals at the expense of value maximization underlies the models of Grossman and Hart (1982), Stulz (1990), Hart and Moore (1990) and Hart (1993). Related models by Williamson (1988) and Harris and Raviv (1990) consider the possibility that debt may force managers to reduce the size of the firm by liquidating inefficient operations. See Harris and Raviv (1991) for an extensive survey of capital structure models. 
managers to increase leverage beyond the optimal point, in order to inflate the voting power of their equity stakes and reduce the possibility of takeover attempts. A third possibility is that entrenched managers sometimes adopt excess leverage as a transitory device that signals a commitment to sell assets or otherwise restructure, thereby preempting takeover attempts by outsiders who might have different plans for increasing firm value.

Our empirical analysis has two goals. First, we explore whether significant associations exist between patterns of firm leverage and variables that are associated with managerial entrenchment. Second, we evaluate how closely our findings support each of the three theories advanced above about how entrenchment might affect managers' leverage choices.

- We begin by documenting cross-sectional relations between the levels of various corporate governance variables and firms' debt/equity ratios. After controlling for non-agency determinants of leverage, we find significantly lower leverage in firms whose CEOs have several characteristics of entrenchment, including a long tenure in office and compensation that has low sensitivity to performance. Leverage is also significantly lower when CEOs do not appear to face strong monitoring, as is the case when the board of directors is large or has a low fraction of outside directors, and when the firm has no major stockholders. We recognize that many of these crosssectional levels results are also consistent with other theories of corporate governance and capital structure. Therefore, we undertake further analysis to explore the impact on firms' capital structures of large, discrete changes in corporate governance parameters. We find that in the aftermath of events that represent negative shocks to CEO security, including attempts to acquire the firm, the involuntary departure of the prior CEO, and the arrival of a major stockholder-director, firms' subsequent capital structures exhibit significantly greater leverage. We also find that leverage 
increases after CEOs are subjected to greater performance incentives in the form of increased inventories of stock options. Our results strongly suggest that the degree of managerial entrenchment has influence on firms' observed capital structures, and these findings represent the major contribution of the paper.

We extend our analysis by examining news stories about our sample firms around the time of entrenchment shocks, seeking confirmation of a direct link between the events and the leverage changes. We also seek to evaluate three possible explanations for why managers might be motivated to change leverage when their security is threatened: to increase the firm value by moving toward a more beneficial, though less comfortable, capital structure; to increase their personal voting control; or to commit to a defensive restructuring that, while not necessarily optimal, creates sufficient value to keep raiders away. These three theories are not mutually exclusive, and we find that each has some explanatory power.

After unsuccessful takeovers, we find net debt issued and equity repurchased both increase markedly, while new equity issued also increases, albeit less substantially. We find that the increase in net debt is generally used to finance large special dividends, equity repurchase offers, or restructuring of operations. Consistent with empirical findings by Safieddine and Titman (1996) of large and significant improvements in operating and stock performance following leverage increases, and with arguments by Grossman and Hart (1982), Jensen (1986), and Stulz (1990), these uses of funds suggest that debt generally helps firms remain independent by committing them to undertake operating improvements that the potential acquirer would otherwise make.

Forced CEO replacements and the addition of blockholders to the board are both followed by leverage increases that, while substantial, are not as large as those following unsuccessful 
takeovers. Both of these leverage changes arise almost exclusively from a substantial issuance of new debt. An examination of the events following forced $\mathrm{CEO}$ replacements shows that the new debt usually finances special dividends or operational restructuring.

Since we find that special dividends and restructurings often occur after leverage rises, our results are superficially consistent with the theory that managers use leverage as a defensive device to commit to value-increasing changes. However, we observe this pattern of events not just after failed attempts to acquire the firm, but also after entrenchment-reducing events that are not necessarily related to takeover threats, including the dismissal of the prior CEO and the arrival of a major stockholder on the board of directors. Therefore, we think the sample-wide results cannot be explained completely as temporary tactical moves to deter outside raiders. Rather, our findings also seem consistent with a conjecture that most firms have less leverage in their capital structure than optimal, and that managers who sense threats to their security increase leverage permanently as a value-enhancing action which they would otherwise prefer to avoid. Our parallel finding that leverage increases after managers receive large incentive compensation awards also seems to support this view. We further explore this possibility by analyzing how leverage changes after entrenchment shocks as a function of a firm's apparent leverage deficit or surplus at the start of each year. We find that firms with leverage deficits react to threats to entrenchment by levering themselves beyond the predicted level, whereas no significant changes are observed for firms with leverage surpluses.

However, certain of our results are also consistent with the theory that managers take on excessive leverage in order to bolster their entrenchment, since we observe a positive cross-sectional association between leverage and managerial voting power, consistent with Stulz (1988).

Section I elaborates on the effect of entrenchment on managers' leverage decisions. Section 
II presents our analysis of leverage levels, including sample selection, variable construction, and empirical results. Section III presents similar information for the changes analysis. We summarize the results and offer conclusions in section IV.

\section{Managerial Entrenchment and Leverage}

A large literature has followed Grossman and Hart (1982) by using an ex ante efficiency perspective to derive predictions about a firm's financing decisions in an agency setting. Theories in these papers emphasize debt's role in lowering agency problems between managers and shareholders, but they ignore the agency problem to which the leverage choice itself is subject. Conflicts of interest over financing policy arise between managers and shareholders because of such factors as managers' preference for lower firm risk due to their underdiversification (Fama (1980), Amihud and Lev (1981)), managers' disutility from being subject to the performance pressure that large fixed interest payments entail (Jensen (1986)), and managers' preference for job retention when others are better qualified (Harris and Raviv (1988), Stulz (1988)).

Models using the ex ante efficiency perspective generally adopt the viewpoint of an initial entrepreneur seeking to maximize firm value, with some disciplinary mechanism forcing the entrepreneur to choose the value-maximizing debt level. Novaes and Zingales (1995) show, however, that the efficient choice of debt (optimal for shareholders) generally differs from the

entrenchment choice (optimal for managers whose objective is to maximize tenure). Moreover, if the disciplinary mechanism (in their case takeover pressure) has high costs, managers underlever, whereas if takeovers are cheaper than debt as a disciplinary device, managers overlever to block takeovers. Jung, Kim, and Stulz (1996) find some support for entrenchment affecting leverage 
decisions. They show that a significant portion of equity issuers are firms with poor investment opportunities that have not exhausted their debt capacity. These firms also invest more than similar firms issuing debt. The Jung, Kim and Stulz results thus support the notion that agency costs of managerial discretion lead certain firms to issue equity when debt issuance would have better consequences for firm value.

Theoretical arguments and some empirical evidence thus point to the possibility that managers can become entrenched, and that they may deviate from choosing optimal leverage as a result of the agency costs of managerial discretion. These arguments do not, however, resolve whether entrenched managers tend to take on too little or too much debt, ${ }^{2}$ and an important goal of our research is to cast more light on this issue.

\section{Analysis of Capital Structure Levels}

In this section we analyze companies' relative levels of leverage as a function of corporate governance variables. If entrenched managers systematically make suboptimal decisions about capital structure, we should observe significant cross-sectional associations between leverage and variables that indicate greater entrenchment. Prior studies by Friend and Lang (1988) and Mehran (1992) present some evidence consistent with this view. We extend their results in this section as a prelude to our inquiry in section III, in which we investigate whether large changes in entrenchment-related governance variables lead to major changes in leverage.

${ }^{2}$ For example, Zwiebel (1994) presents a model in which entrenchment is determined endogenously. His predictions are that managers of the best-performing firms engage in the greatest degree of empire building, and that managers adopt increasing debt levels as their tenure increases. 
Section II.A discusses the sample selection. Section II.B describes the main dependent and control variables. Many of our controls are similar to those used in the study of cross-sectional leverage by Titman and Wessels (1988). Section II.C describes our empirical results.

\section{A. Sample Selection}

Our analysis uses a dataset of 452 industrial companies between 1984 and 1991 assembled by Yermack (1996). The panel is drawn from annual Forbes magazine rankings of the 500 largest U.S. public corporations based on sales, total assets, market capitalization, and net income. The sample selection rule requires each company to qualify for at least one Forbes list during at least four years of the 1984-91 period, with companies allowed to enter and exit the panel over time. We merge corporate governance and equity ownership data gathered from company proxy statements with accounting data drawn from the Compustat database. We exclude financial firms (SIC codes 6000 through 6999) and utilities (SIC codes 4900 through 4999) due to the marked differences in leverage and corporate governance between those industries and other sectors of the economy. Because some companies have missing values or have been deleted from recent releases of the Compustat database, our sample consists of 3,085 observations for 434 firms over eight years.

Our sample selection criteria limit our analysis to large firms only. While this approach enables us to economize on the time and cost for data collection, the conclusions of our analysis do not necessarily apply to smaller firms. But because the large companies in our sample represent a substantial fraction of the market capitalization of all U.S. public companies, the results should illuminate significant links between capital structure choices and managerial entrenchment. 


\section{B. Variables for Analysis of Leverage Levels}

Table I lists the major dependent and explanatory variables for our analysis of company leverage levels. We measure the level of leverage at the end of each fiscal year using two continuous variables that take values between 0 and 1 :

$$
\text { Leverage (book value) }=\frac{\text { total debt }(\text { book value })}{\text { total assets }(\text { book value })}
$$

Leverage (market value $)=\frac{\text { total debt (book value })}{\text { total debt (book value })+ \text { common equity (market value })}$

To assess the influence of CEO entrenchment and control upon capital structure choice, we estimate a variety of regression models of these two variables, using as regressors several variables that appear widely in corporate governance studies. Our data is gathered from proxy statements filed in advance of firms' annual shareholder meetings, which usually occur in the fourth or fifth month of each fiscal year.

Jensen and Meckling (1976) and other authors have identified managerial equity ownership as an important influence upon firm value, and we therefore include in our model the CEO's direct stock ownership, measured as a percentage of common equity. We expect that CEOs will have more powerful incentives to make value-maximizing decisions about capital structure when their stock ownership is high, although, as claimed in Mørck, Shleifer, and Vishny (1988), this may not hold true over all ranges since high ownership may insulate managers against other disciplinary forces. Therefore, we cannot make an unambiguous prediction about the association between CEO ownership and leverage.

Our models also include a variable measuring the CEO's holdings of stock options 
exercisable within 60 days, again as a percentage of common shares (data is unavailable for unexercisable options). While this variable should further help us measure the interaction between CEO ownership and leverage, it probably serves a more important purpose in providing a measure of the CEO's performance-based incentive compensation, which usually depends heavily on stock options (Jensen and Murphy (1990); Yermack (1995)). We view a CEO as entrenched if his compensation is not sensitive to performance; if entrenched CEOs prefer low (high) leverage, we expect to observe positive (negative) coefficient estimates for the stock option variable.

A related characteristic of entrenched CEOs should be a high level of fixed compensation, since one might expect entrenched managers to extract excessive resources from the firm. We use cash salary and bonus payments as a proxy for fixed compensation since estimates in Jensen and Murphy (1990), replicated by Yermack (1996) using our data, indicate that CEOs' salary and bonus compensation has extremely low sensitivity to changes in firm value. We define excess fixed compensation as the residual in the ordinary least squares (OLS) regression:

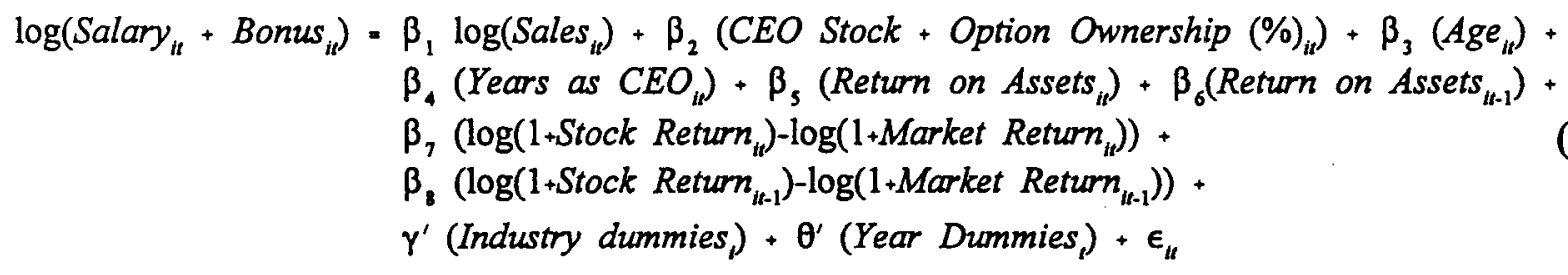

The subscripts $i$ and $t$ represent firms and years, respectively, and all dollar values are adjusted for inflation. If entrenched CEOs prefer low (high) leverage, we expect to observe negative (positive) estimates for this variable.

We use a variable measuring the CEO's years in office to reflect the likelihood that a CEO's control over internal monitoring mechanisms increases as his tenure lengthens. An entrenched CEO 
who is insulated from the threat of dismissal will also exhibit a large number of years in office. We use the natural $\log$ of this variable, in the belief that CEO power over corporate governance will cumulate over time at a decreasing rate.

Our models include several variables related to the strength of monitoring faced by the CEO, since a further characteristic of entrenchment is the absence of effective monitors. We use an indicator variable that equals one if the company reports having one or more holders of at least $5 \%$ of the common stock (we ignore company-sponsored ESOP plans), since large blockholders have large, direct incentives to monitor managers actively. Several studies, such as Weisbach (1988), indicate that top managers face more vigorous monitoring when the board of directors is controlled by independent or outside directors. To capture the importance of this effect, we include a variable measuring the percentage of the board comprised of outside directors. The variable excludes "grey" directors who have personal business relationships with the company or are relatives of current or former officers. A related variable in our models measures the size of the board in a log specification. Board size has been identified as an important determinant of corporate governance effectiveness in theoretical papers by Lipton and Lorsch (1992) and Jensen (1993). An empirical study by Yermack (1996) shows a significant association between board size and firm value, and also presents results indicating that $\mathrm{CEO}$ disciplinary mechanisms related to compensation and the threat of dismissal lose power as board size increases.

In addition to these corporate governance variables, we include in our models standard control variables for other firm attributes expected to influence leverage. To control for company profitability, we use a return on assets (ROA) variable defined as earnings before depreciation, interest, and taxes, divided by total assets at the start of the year. We measure company size by 
using the book value of assets in place (the log of total assets). ${ }^{3}$ We control for non-debt tax effects by using the ratio of investment tax credits over total assets. The collateral value of assets is measured by the ratio of net property, plant, and equipment plus inventory over total assets. Two variables are included to measure the uniqueness of assets: research \& development (R\&D) expense over sales (which also proxies for the presence of growth opportunities), and selling, general, and administrative (SGA) expenses over sales.

Table I gives the definitions of dependent and explanatory variables, along with sample-wide means and standard deviations. The table also shows sample correlations between the explanatory variables and one of our leverage measures; the majority of these correlations have the same sign as regression coefficient estimates presented in the next section.

\section{Regression Results}

Table II presents regression estimates of models of leverage levels. The table shows three types of estimates: OLS, "between" estimates based on the variation of the intra-firm means of all variables, and "within" estimates based on the variation of the data within each firm. Between estimates are presented to address concerns that observations drawn repeatedly from the same sample of firms may not be independent. Within estimates adjust for the possibility that unobservable, firm-specific factors influence the level of leverage in each individual company; the within estimates are equivalent to estimating OLS models and including indicator variables for each of the 434 firms. The left side of Table II shows the three estimates based on models using our book

3 No material change occurs in our results if we reestimate our models using a market value measure of firm size (the $\log$ of the sum of the market value of equity plus the book value of total debt). 
value specification of leverage, while the right side of the table shows estimates based on a market value specification. Indicator variables for individual years are included in all models, and two-digit SIC industry indicators appear in all models except the within estimates.

Results in Table II generally support the hypothesis that entrenched CEOs seek to avoid leverage. However, we are hesitant to draw strong conclusions from our levels analysis alone, since competing theories about corporate governance lead to similar predictions about how companies should design their capital structures in order to reduce agency costs and increase firm value. Moreover, many of the variables in our models of leverage levels are likely determined simultaneously, making it difficult to ascertain cause-and-effect relations from estimated regression coefficients. Few substantive differences appear to exist between the models using the book value and market value estimates of the dependent variable, but the method of estimation does affect the significance of certain explanatory variables. Most of our financial control variables generally have signs in line with accepted theories of capital structure, and to conserve space we confine our discussion to those variables related to the hypotheses about the relation between leverage and managerial entrenchment.

Our regressions show a positive and generally significant association between firm leverage and CEO direct stock ownership. These findings are consistent with an interpretation that managers whose financial incentives are more closely tied to stockholder wealth will pursue more levered capital structures to raise the value of the company. However, the findings also support the conjecture of Stulz (1988) that managers might increase leverage as a means of consolidating their own voting control. Regardless of the interpretation, the economic significance of these estimates appears low; the estimates in the range of 0.1 to 0.2 imply only modest changes in leverage in 
relation to reasonable changes in the fraction of the equity held by a $\mathrm{CEO}$, which exhibits a mean of 0.027 and standard deviation of 0.079 .

Estimates for executive compensation variables also point to an inverse association between leverage and managerial entrenchment. Our results show a significantly positive relation between leverage and CEO vested option holdings. This finding suggests that CEOs who are not entrenched, because they face financial pressure from compensation tied to firm value, will take on greater debt. However, the option result is also consistent with arguments by Haugen and Senbet (1981) and Smith and Watts (1982, 1992), as well as empirical evidence in DeFusco, Johnson, and Zorn (1990), that stock options may motivate managers to increase firm risk. It is also difficult to evaluate the importance of the option holdings variable since we have no data about the unexercisable options held by CEOs. Interestingly, however, the option variable appears to have far greater economic significance than the variable for direct stock ownership, as its estimated coefficients are an order of magnitude larger. We do not have a clear explanation for this difference.

Our measure of the CEO's excess fixed compensation has near zero association with leverage in the OLS and between models, but a significantly negative estimated association in the within models. These latter results are consistent with entrenched CEOs taking on less debt, if one assumes that entrenched CEOs also succeed in becoming over-compensated. However, these estimates are not robust to the specification of the excess compensation variable; if one includes the Black-Scholes value of stock options as part of the CEO's annual compensation, the estimates are no longer significant.

The CEO's tenure in office has a negative estimated association with the level of leverage, though estimates are significant only for the dependent variable based on market values. The 
estimates are consistent with entrenched CEOs pursuing capital structures with lower leverage, perhaps to reduce the performance pressures that accompany high debt. However, as is the case for many of the variables in this model, the result supports alternative interpretations. For example, it is possible that $\mathrm{CEO}$ tenure is positively correlated with managerial quality or skill. High-quality CEOs may have presided over many years in which their firms' stock prices rose at an above-average rate, resulting in capital structures with a high market value of equity. Again, the variable has modest economic significance; the estimate of -0.008 in the right column implies that leverage decreases by about 0.5 percent of assets as CEO tenure doubles.

Variables associated with stronger monitoring also have positive connections with leverage, reinforcing our interpretation that entrenched CEOs attempt to avoid debt. Our results indicate that leverage rises in the presence of a significant blockholder, as the indicator variable for the presence of a $5 \%$ stockholder is uniformly positive and significant in three out of six models, and the estimates suggest that firms with blockholders have leverage $1 \%$ to $4 \%$ higher than other firms. This finding suggests that managers are forced to take on more debt when an influential monitor is present, and that board blockholders and debtholders act as monitoring complements rather than substitutes. Board size has a consistently negative estimated association with leverage across all six models and is significant in four out of six estimations. If CEOs with small boards are less entrenched due to superior monitoring by these bodies, an inverse association between board size and leverage is consistent with the prediction that entrenched CEOs pursue lower leverage. The coefficient estimate of -0.062 in the right column implies an increase in leverage on the order of $4 \%$ if board size is halved. The presence of outside directors on the board seems to lead to greater leverage, although the strength of this assertion relies on the significant estimates for our two within 
models and the OLS model of market leverage. We conjecture that boards with more outside directors monitor CEOs more actively, causing these managers to adopt capital structures with more leverage.

Several of the results from our analysis of capital structure levels are similar to those reported by Mehran (1992), who examines a sample of 124 manufacturing firms during 1973-1983. Mehran reports OLS estimates of regressions of the level of book leverage against ownership, board structure, and control variables. Using similar measures, he documents OLS results qualitatively the same as our Table II book leverage OLS results with respect to the effects of CEO direct stock ownership, asset collateral value, and the ratio of R\&D to sales. Mehran also finds that the percentage of the CEO's total compensation awarded as stock options (as opposed to the percentage of common shares held in options that we report) has a marginally positive association with book leverage.

\section{Analysis of Changes in Capital Structure}

As noted in the preceding discussion, many variables related to capital structure, firm performance, and corporate governance are likely determined simultaneously, making any analysis of cross-sectional levels difficult to interpret. Further, as MacKie-Mason (1990) notes, debt/equity ratios represent the cumulative result of years of separate decisions, meaning that tests based on a single aggregate of different decisions are likely to have low power. For these reasons we feel that agency-based models of leverage may be better studied by analyzing decisions to change leverage, 
rather than the cross-sectional variation in debt/equity ratios. ${ }^{4}$ Our research strategy is to study whether leverage changes significantly after events that appear to represent exogenous shocks to companies' governance structures.

Section III.A discusses the variables used in our analysis. Section III.B presents estimates for regression models of changes in leverage. Section III.C explores how changes in leverage differ for firms that appear ex ante to have low and high levels of leverage.

\section{A. Variables for Analysis of Changes in Leverage}

Key dependent and explanatory variables for our analysis of changes in leverage appear in Table III. We measure changes in the debt and equity components of leverage with the following variables, all based on annual flow of funds data obtained from Compustat:

$$
\begin{gathered}
\text { Net issuance of debt }=\frac{\text { debt issued }- \text { debt retired }}{\text { total assets }} \\
\text { Equity issued }=\frac{\text { new equity issued }}{\text { total assets }} \\
\text { Equity repurchased }=\frac{\text { equity repurchased }}{\text { total assets }}
\end{gathered}
$$

The variables in equations 4,5 , and 6 are combined into a single variable measuring the net change in leverage over the course of a fiscal year. The variable is constructed so that a positive value indicates an increase in leverage:

\footnotetext{
${ }^{4}$ See Jung, Kim, and Stulz (1996) for an elaboration of this view.
} 


$$
\text { Net leverage change }=\frac{\text { net debt issued }- \text { equity issued }+ \text { equity repurchased }}{\text { total assets }}
$$

Total assets is measured at the start of the year for all of the dependent variables. We lose about $30 \%$ of our observations from the levels analysis, because some of our explanatory variables for changes in leverage are based on first differences within our eight-year panel data, and also because of missing values on Compustat for one or more of the flow-of-funds variables. Our sample for analysis of leverage changes therefore has 2,196 observations from 409 companies. We also analyze three alternative specifications of our main dependent variable (equation 7 ). The first alternative dependent variable uses the same net issuances numerator but replaces the denominator with the market value rather than the book value of total assets. The other two alternative dependent variables are annual changes in leverage based on both book value and market value debt ratios. Results from all of these models are qualitatively similar, and we do not report them in order to conserve space.

Related prior studies of capital structure changes have relied on data from the SEC's Registered Offerings Statistics (ROS) tape. For several reasons we use Compustat flow-of-funds data instead. ${ }^{5}$ The ROS tape does not capture important events related to changes in leverage, such as stock repurchases, retirements of debt, issuances of non-public debt (especially bank debt), and issuances of new equity for such events as mergers and acquisitions. It is also difficult to construct continuous variables from data on the ROS tape, since the amount of funds actually raised from the

\footnotetext{
${ }^{5}$ Opler and Titman (1996) also use Compustat flow of funds data to identify changes in leverage. Their study does
} not, however, use continuous dependent variables, but rather indicator variables that equal one if a firm's annual debt or equity issuance exceeds $5 \%$ of total assets. 
offerings listed on the tape are generally less than the amount registered with the SEC. Finally, time lags of varying length exist between the dates on which securities issues are registered with the SEC and the dates they are actually sold to the public. Although the flow-of-funds data from Compustat overcome many of these problems, they also raise some concerns. Some capital structure changes occur as the result of actions by outside claim holders, such as the exercise of stock options or warrants or the conversion of convertible debt into equity. Because our analysis seeks to isolate capital structure changes that occur because of managerial choices, the Compustat data captures some extraneous information that we would have liked to ignore.

To investigate whether leverage changes are related to exogenous changes in the degree of managerial entrenchment, we require explanatory variables that one would expect to be associated with discrete, meaningful changes in the security of top management. We identify several corporate governance events that typically indicate a significant threat to managerial security: an outside offer to acquire the firm, the replacement of the company's CEO, and the addition to the board of directors of a major stockholder.

We expect that managers feel great pressure to raise the value of the firm in the aftermath of failed acquisition attempts, and we use the Lexis/Nexis data retrieval system to search the database of Investment Dealer's Digest for reports of unsuccessful tender offers made between 1984 and 1991 for our sample companies. We construct an indicator variable for unsuccessful tender offers and set it equal to one if an offer that subsequently fails is made during a fiscal year (when the offer occurs in the final month of a fiscal year, the variable is set equal to one for the following year's observation instead).

A new CEO should have relatively low job security, particularly in those cases when the 
board has acted to remove his predecessor. We create an indicator variable for new CEOs that equals one if the predecessor CEO left during the last six months of the prior year or the first six months of the current year. We also consider a more narrow specification of the CEO turnover variable, setting the indicator variable equal to one only for cases where the prior CEO's departure was likely forced or involuntary. We place turnover episodes into this involuntary category if the exiting CEO is age 62 or less and does not remain a member of the company's board of directors. We then check news stories about each CEO's departure to ensure that we do not misclassify departures that are actually voluntary, resulting in the exclusion of two cases in which the CEO left voluntarily for a similar position at another firm. For analysis using this involuntary turnover variable, we set equal to missing all other observations where the $\mathrm{CEO}$ leaves his position.

The addition to the board of a major stockholder may portend pressure for management to undertake value-increasing changes or face the threat of replacement. We create an indicator variable equal to one if the number of $5 \%$ stockholder-directors, as reported in the mid-year proxy statement, rises by at least one compared to the prior year's value. We also test specifications of the variable based on the number of $5 \%$ stockholders, regardless of whether they are members of the board, but obtain no significant results.

Figure 1 shows graphically how leverage changes around each of the three events that we study. The graph shows mean values of the ratio of total debt to total assets for the subsamples of firms affected by each event, in a time series beginning three years before the event year and extending until three years after (the event year occurs between years $t$ and $t_{+1}$ on the graph). Leverage increases substantially during the event year and appears to remain permanently higher in each of the three subgroups; the event-year changes in mean leverage are $+11.9 \%$ for firms subject 
to unsuccessful tender offers, $+6.1 \%$ for firms whose CEO leaves involuntarily, and $+5.0 \%$ for firms in which a major stockholder joins the board. The dotted line, representing all other observations, has a gentle upward slope, representing a secular increase in leverage of about $+0.5 \%$ per year for our sample firms between 1984-91. Data for sample medians (not shown) exhibit a similar pattern with lower magnitude: the changes in median leverage are $+4.6 \%$ for firms subject to unsuccessful tender offers, $+1.2 \%$ for firms whose CEO leaves involuntarily, and $+1.9 \%$ for firms in which a major stockholder joins the board, compared to a change in median leverage of $+0.7 \%$ for all other firm-year observations in the sample. Not much overlap exists among the three events that we analyze: $86 \%$ of the unsuccessful tender offers, $73 \%$ of the forced CEO replacements, and $89 \%$ of the new stockholder-director episodes occur in the absence of either of the other two, although less formal corporate control activity may have coincided with some events in the latter two categories. The seemingly permanent change in leverage after entrenchment shocks seems to argue against the theory that managers increase debt transitorily to commit to a defensive strategy of generating cash by selling assets or restructuring operations.

Control variables for our regressions analyzing changes in leverage are similar to those used to study the level of leverage. We take first differences of our governance variables related to CEO stock ownership and board composition. We add several additional explanatory variables so that our model's specification is similar to those of two other studies: MacKie-Mason's (1990) investigation of how changes in leverage are related to differences in marginal tax rates, and Jung, Kim and Stulz's (1996) study of how financing decisions are related to investment opportunities and agency considerations. Our additional control variables are the ratio of a firm's market value over book value at the start of the year, its leverage at the start of the year, its stock return during the 
preceding year, and the ratio of net operating loss carryforwards (as reported by Compustat) over total assets. We define the market-to-book ratio as the market value of equity, plus the book value of total assets, minus the book value of equity, all divided by the book value of total assets. We also include indicator variables for each year in our model in order to capture macroeconomic influences.

\section{B. Regression Results}

Table IV presents OLS estimates for our model of net year-to-year changes in leverage. We show estimates for models using separately each of our explanatory variables that are intended to reflect sudden, significant threats to managerial security.

- We find sizeable, significant increases in leverage occurring in years that firms face unsuccessful tender offers. As shown by the estimated regression coefficient in the first column of Table IV, unsuccessful tender offers are followed the next year by increases in book leverage on the order of $12.9 \%$ of total assets. Table $\mathrm{V}$ provides a more detailed look at how the components of leverage change. The table shows estimated regression coefficients for models where the dependent variables are the net change in debt, issuances of new equity, and repurchases of equity, all scaled by total assets. Estimates in the first row of Table $\mathrm{V}$ suggest that firms that defeat takeover attempts become heavy purchasers of their own stock, at an average level of $4.7 \%$ of total assets, with these buybacks apparently financed by new debt, which is issued in an average amount of $12.0 \%$ of total assets. The rise in debt after an unsuccessful offer is consistent with Ofek's (1994) finding that debt increases after unsuccessful management buyouts. Interestingly, some of the firms experiencing unsuccessful tender offers also appear to issue equity, as the estimated coefficient for equity issuances is positive and significant at $2.9 \%$ of total assets, which represents a lower magnitude than 
the coefficients for the other two leverage components.

The results provide evidence of increases in leverage after unsuccessful takeover attempts, but several explanations of the pattern are possible.

If managers carry a suboptimal amount of debt because of their dislike of risk and performance pressure, the leverage increases we observe may simply represent moves in the direction a value-increasing debt/equity mix which managers otherwise would like to avoid. This interpretation appears consistent with Saffieddine and Titman's (1996) analysis of 573 firms that were targets of unsuccessful takeovers between 1982 and 1991. Saffieddine and Titman find significant increases in leverage after the takeover attempts, as well as a positive relation between the change in leverage and subsequent operating performance and stock returns.

Alternatively, the heavy repurchases of stock after unsuccessful tender offers could represent greenmail payments or attempts by managers to increase their own voting power, consistent with Stulz (1988). One could also view higher leverage after unsuccessful tender offers as a type of "scorched earth" tactic in which managers lever the firm as a defensive measure to buy time and credibly commit to a restructuring plan. Saffieddine and Titman's results are not necessarily inconsistent with this theory, since they observe increases in firm performance when leverage is increased after failed takeover attempts and cannot observe how well their sample firms would have performed had the takeovers succeeded. However, direct empirical evidence for the effectiveness of leverage as an entrenchment device is mixed. Dann and DeAngelo (1988) conclude that a broad class of defensive adjustments entrenches target management, but Denis (1990) finds that defensive payouts do not prevent high management turnover following the control contest, nor the frequent adoption by the target of restructuring programs tied directly to the control battle and the defensive 
payout. Moreover, even if defensive recapitalizations do increase the security of managers, they serve a beneficial purpose by forcing the disgorgement of resources to shareholders.

We examine news stories about companies in our sample to gather more information about the timing and motive for leverage changes that occur in the same year as failed tender offers. We first seek to verify that the leverage increases usually occur after and not before the takeover bids. We base this assessment on the dollar amounts revealed in news stories of public issuances and redemptions of debt and equity for the 21 of $35^{6}$ targets of unsuccessful takeovers that increased leverage by more than $2 \%$ in the event year. We find, based on an equal-weighted average across the 21 firms, that $98.6 \%$ of the publicly disclosed dollar value of leverage increase during the fiscal year of the unsuccessful takeover occurs after the date of the offer.

We also seek to assess whether a direct link exists between the takeover offer and the leverage increase, and, if so, to identify the purpose(s) of the leverage increase. For 17 of the 21 firms $(81 \%)$ we find news stories expressing a direct link between the leverage increase and the takeover offer. The increase in net debt in these 17 firms is generally used to finance large special dividends, equity repurchase tender offers, or restructuring of operations. These uses of funds suggest that the leverage increase generally helps firms remain independent by committing them to undertake the improvements that the potential acquirer would make.

For five firms, however, the net debt increase is used for either general corporate purposes, to pay greenmail that exceeds the amount of any repurchase tender offers, or to engage in the "Pac-

\footnotetext{
${ }^{6}$ Note that eight of these 35 firms drop out of our regression analysis due to missing values for one or more explanatory variables, accounting for the sample size of 27 reported in Figure 1. Similar patterns of missing values affect the sample size for our measures of involuntary CEO turnover and the presence of large blockholders on the board of directors.
} 
Man" defense of purchasing the prospective acquirer. The uses of funds from the leverage increase in this minority of target firms are consistent with levering up being a defensive response that increases entrenchment and keeps managers in command of the same resources as before.

We do not find a systematic pattern in the use of proceeds by firms that issue significant amounts of new equity.

Returning to our regression analysis in Table IV, we find that another episode representing a threat to managerial security, the replacement of a company's CEO, also leads to greater ex-post leverage. The coefficient on the CEO replacement variable in the second column of Table IV is positive at $0.7 \%$ of total assets, though not significant. Redefining this variable to narrow the CEO turnover episodes to those cases likely to have been forced or involuntary -- when the exiting CEO is age 62 or less, does not remain on the company's board, and is not described in news stories as leaving to take a similar position at another firm -- dramatically increases the magnitude and significance of the coefficient estimate. As shown by the third column of Table IV, leverage rises by $8.8 \%$ of total assets in years following the forced departure of a CEO. Table V suggests that new debt issues account for the majority of this total, with some funds devoted to stock repurchases as well.

We read news stories published around the time of these CEO turnover events in an attempt to narrow further our sample of forced turnover events. Of the 34 episodes that we originally classify as involuntary turnover, 11 are accompanied by news reports whose language clearly indicates that the CEO was forced out by the board. ${ }^{7}$ When the analysis in Table IV is repeated

\footnotetext{
${ }^{7}$ This language includes such information as the former CEO suing the firm and/or board members over his dismissal, the former CEO having no part in the decision to replace him, the replacement being the result of a board power
} 
using only this group of observations, the coefficient on the involuntary turnover variable rises substantially, to approximately 0.30 , and remains significant at better than the $1 \%$ level.

We also use these news stories to assess the timing of any leverage increases exceeding $2 \%$ of assets that occur in the fiscal year of the CEO replacement, and to assess the use of funds in these cases. An equal-weighted average across the 17 forced $\mathrm{CEO}$ replacements accompanied by leverage increases exceeding $2 \%$ reveals that $73.3 \%$ of the publicly disclosed dollar value of the leverage increase during the fiscal year of the replacement occurs after the date that the new CEO is appointed. Only six (35\%) of these 17 firms have news stories that clearly indicate a direct link between the replacement and the leverage increase. In all but one of these six cases the use of the debt increase is to pay special dividends or to restructure operationally, with the remaining firm stating it was using the funds for general corporate purposes.

Our third variable indicating a threat to managerial entrenchment, an increase in the number of $5 \%$ stockholder-directors, is also associated with greater leverage. Estimates in the fourth column of Table IV suggest that leverage rises by $6.9 \%$ in the year following the addition of a blockholder to the board. Table V indicates that this effect is largely due to new issues of debt. We do not pursue an examination of news stories related to the arrival of new blockholder-directors, because we are generally unable to date precisely when these events occur.

Our three events indicating threats to managerial security -- unsuccessful tender offers, involuntary CEO replacements, and the arrival of major stockholder-directors -- coincide for some observations, as discussed previously. To increase our confidence that each of these events, by itself,

\footnotetext{
struggle or a takeover, and the direct phrasing that the board "forced out" the former CEO.
} 
carries sufficient importance to cause CEOs to increase leverage, we estimate a final regression model and include all three indicator variables. As shown in the right column of Table IV, the coefficient on each variable remains strongly positive and significant. Two of the three coefficients decline slightly in magnitude compared to the models in which they appear alone, a pattern that should be expected due to the existence of some overlap events in our sample.

A further result, consistent across every specification in Table IV, is that leverage increases when CEOs' holdings of exercisable stock options increase. This finding implies that when CEOs are subject to greater performance incentives tied to the value of the firm, they are more likely to take on higher debt levels. The effect appears to have economic as well as statistical significance: for a one standard deviation change in the independent variable, the estimated change in leverage is plus or minus $1.9 \%$ of debt over total assets. Interestingly, this result remains positive but has less magnitude and no statistical significance if the variable is specified as the number of new options awarded divided by shares outstanding, rather than the change in options held. This suggests that measuring $\mathrm{CEO}$ incentives simply by counting the number of new options awarded ignores the diminution in incentives that occurs due to the exercise or expiration of previously held options.

Finally, one result among our control variables in Table IV is somewhat puzzling: we find that firms become more levered when their market-to-book ratios are high, although many prior studies have found that firms are especially likely to issue equity under these conditions. Further analysis of the data shows that high market-to-book firms are more likely to issue both new equity and new debt. These results suggest that firms with high market values have many investment opportunities that motivate them to raise funds from all types of sources. We further find that firms with a high market-to-book ratio are also more likely to repurchase their own stock, and this effect 
accounts for the overall change in leverage being positively associated with a high market-to-book ratio.

Prior studies such as Opler and Titman (1996) have found that firms with high market-tobook ratios are more likely to choose equity over debt, given that they decide to raise external funds. Our results are not necessarily inconsistent, since our models use continuous instead of binary dependent variables, our analysis includes stock repurchases as part of the leverage change, and our sample does not exclude those firms that issue both securities as well as the large majority of firmyear observations in which a company does not issue substantial amounts of either security. To check our results for sample selection bias, we replicate the analysis of Opler and Titman (1996) using our data, and we obtain estimates with similar magnitude and significance for most variables, especially the market-to-book ratio. We also check whether our market-to-book coefficient is driven by multicollinearity, reestimating our model after dropping the variables measuring the collateral value of assets, R\&D over sales, and SGA over sales (we drop each variable separately and then drop all three from the model). No coefficients exhibit a meaningful change in magnitude or significance in any of these re-estimations, and the estimates also prove robust to dropping the market-to-book variable itself.

\section{Leverage Changes in Low- and High-Leverage Firms}

Our main results in Table IV indicate that managers increase leverage in response to shocks that reduce their entrenchment. However, we note in our discussion above that more leverage may not always represent a value-increasing strategy, and it is possible that CEOs overlever their firms beyond the value-maximizing level as a defensive measure when their security is threatened. 
We explore this issue further by analyzing how leverage changes as a function of a firm's apparent leverage deficit or surplus at the start of the year. We use our model of leverage levels, introduced earlier in this paper, to estimate predicted values of leverage for all our observations. The specification of the model used for this purpose is identical to that in the first column of Table II, except that we exclude the corporate governance variables appearing in the first seven rows of the table. Next, we regress firms' annual changes in leverage, using our Compustat flow-of-funds variables, against the control variables used in Table IV and the leverage surplus at the start of the year, with the surplus defined as the difference between actual and predicted leverage. Table VI shows the results, with the top half of the table displaying estimates for all firms, and the lower half showing estimates over the subsample of firms with less leverage than predicted. The coefficient of -0.166 in the first cell of the table indicates that absent unusual shocks to managerial security, firms generally adjust leverage toward its expected level, closing approximately one-sixth of the surplus or deficit in a given year. The coefficient estimate for underlevered firms on the bottom of the table is a very similar -0.139 .

To study the effect of entrenchment shocks, we add to the model interaction terms between the leverage deficit and the indicator variables we use for shocks to managerial security. The next four columns of the table show negative estimates on each of the interaction terms, implying that entrenchment shocks increase the speed at which firms move toward the expected level of leverage (Figure 1 illustrates that firms whose CEOs become subject to entrenchment shocks do not have abnormally low leverage compared to the rest of the sample before shocks occur). Moreover, estimates in the lower half of the table indicate that the effect is pronounced for underlevered firms, with most of the entrenchment shocks causing firms to add leverage that takes them beyond their 
expected levels. For example, underlevered firms experiencing an unsuccessful tender offer tend to close approximately $151 \%$ of the gap between actual and expected leverage, according to the sum of the estimates for the intercept and interaction terms. Underlevered firms close about $233 \%$ of this gap in the year after the involuntary departure of a CEO, and about $198 \%$ of the gap after a major stockholder joins the board. In contrast, estimates for these interaction terms for firms with more leverage than predicted (not shown) are generally positive rather than negative and are not statistically significant, suggesting that leverage also increases or stays unchanged for overlevered firms. The very large effects observed for underlevered firms appear to cause the negative estimates for the overall sample.

We check our results by re-estimating our regression models of leverage changes, introduced in Table IV, over subsamples of firms that appear to be underlevered. The top half of Table VII shows models estimated over the subsample of firms with less leverage than predicted by a regression model, as described above. As expected, when compared to the Table IV results for the full sample, the tendency of CEOs to add leverage in response to diminished entrenchment has uniformly stronger magnitude for all of our main explanatory variables. The magnitude of the key coefficient estimates is roughly $50 \%$ to $100 \%$ higher over the sample of low-leverage firms as compared to the coefficient estimates for all firms. In the lower half of Table VII, we show estimates based on partitioning the sample according to whether the book value of debt over total assets is below 0.35 , chosen arbitrarily to represent a moderate threshold of leverage. For this subsample, which includes about four-fifths of our observations, we again find uniformly stronger increases in leverage in response to events that threaten managerial entrenchment, compared to the leverage 
increases observed for the entire sample. ${ }^{8}$

We conclude that when firms have pursued a low-debt capital structure in the past, an outside event that threatens managerial security is an especially strong predictor of increased leverage. This leverage generally takes firms beyond the expected debt/equity ratio for our sample, though we cannot observe directly whether these firms move to a level of leverage in excess of the valuemaximizing point. We do not observe a converse effect for firms that have pursued a high-debt capital structure, as these companies exhibit no significant change in leverage -- and, in particular, do not reduce leverage in the direction of the expected level -- in the aftermath of shocks to managerial entrenchment. This asymmetric pattern of leverage changes indirectly suggests that most firms have less leverage than optimal in their capital structures. However, it is also possible that a firm's optimal leverage level increases at least temporarily during a period of restructuring or managerial turnover.

\section{Conclusions}

Theories based on Jensen's (1986) argument that leverage reduces managerial discretion imply that managers will not issue the optimal amount of debt without pressure from a disciplining force. Our results support predictions of this type. We find evidence that firm leverage is affected by the degree of managerial entrenchment, and most of our results indicate that entrenched managers seek to avoid debt.

We examine cross-sectional relations between leverage levels and corporate governance

\footnotetext{
${ }^{8}$ However, leverage changes are not significant for those firms that have a debt ratio below 0.35 but an estimated leverage surplus as defined just above, consistent with our findings for all firms that have leverage surpluses.
} 
variables. We find that leverage is lower when the $\mathrm{CEO}$ has a long tenure in office, has weak stock and compensation incentives, and does not face strong monitoring from the board of directors or major stockholders. These results are consistent with CEOs who are entrenched pursuing less levered capital structures but are also open to other interpretations; for example, the positive association we observe between leverage and fractional CEO stock ownership is consistent with Stulz's (1988) theory that managers use leverage to inflate the voting power of their equity.

Since our cross-sectional results do not clarify whether the associations between leverage and corporate governance variables are causal ones, we conduct further analysis into whether leverage changes significantly in the aftermath of events that represent entrenchment-reducing shocks to companies' governance structures. We find that book value leverage increases by an average of about $13 \%$ of assets when firms are targets of unsuccessful tender offers. The targets that increase leverage generally use the funds from new debt to finance large special dividends, equity repurchase offers, or operational restructuring. These uses of proceeds are consistent with theories that entrenched managers use leverage as a defensive commitment device, to buy time for the implementation of their own restructuring program instead of the outside raider's. However, the apparent persistence of higher leverage for two years after unsuccessful takeovers, as shown in Figure 1, seems to argue against this interpretation. Instead, the higher leverage observed after takeovers may simply represent efforts by managers to move toward a more optimal mix of debt and equity, which they would have preferred to have avoided if they had been able to remain highly entrenched.

The replacement of a company's CEO leads to significantly greater leverage when the turnover appears "forced" because the exiting CEO is under age 62 and does not remain on the board 
of directors; leverage rises by about $9 \%$ of total assets in these cases. These events are consistent with decreases in managerial entrenchment leading to increases in leverage, and our examination of news stories following the turnover generally supports this interpretation. Similarly, we find that leverage rises by about $7 \%$ of total assets in the year after a major stockholder joins the board of directors.

To refine our understanding of entrenchment and leverage, we examine how leverage changes as a function of a firm's apparent leverage deficit or surplus at the start of the year. We find that firms with leverage deficits react to threats to entrenchment by levering themselves beyond the predicted level, whereas firms with leverage surpluses respond to these shocks by either not changing or increasing their leverage. In addition, we find that the leverage increases that follow entrenchment-reducing events are much larger for underlevered firms than for all firms. These results are consistent with the average level of leverage for firms in our sample lying below the optimal level, although we cannot observe the value-maximizing leverage point in order to test this conjecture directly. 


\section{References}

Amihud, Yakov, and Baruch Lev, 1981, Risk reduction as a managerial motive for conglomerate mergers, Bell Journal of Economics 12, 605-617.

Dann, Larry Y., and Harry DeAngelo, 1988, Corporate financial policy and corporate control: A study of defensive adjustments in asset and ownership structure, Journal of Financial Economics 20, $87-128$.

DeFusco, Richard A., Robert R. Johnson, and Thomas S. Zorn, 1990, The effect of executive stock option plans on stockholders and bondholders, Journal of Finance 45, 617-627.

Denis, David J., 1990, Defensive changes in corporate payout policy: Share repurchases and special dividends, Journal of Finance 45, 1433-1456.

Fama, Eugene F., 1980, Agency problems and the theory of the firm, Journal of Political Economy 88, 288-307.

Friend, Irwin, and Larry H. P. Lang, 1988, An empirical test of the impact of managerial self-interest on corporate capital structure, Journal of Finance 47, 271-281.

Grossman, Sanford J., and Oliver D. Hart, 1982, Corporate financial structure and managerial incentives, in J. McCall, ed.: The Economics of Information and Uncertainty (University of Chicago Press, Chicago, IL).

Harris, Milton, and Artur Raviv, 1988, Corporate control contests and capital structure, Journal of Financial Economics 20, 55-86.

Harris, Milton, and Artur Raviv, 1990, Capital structure and the informational role of debt, Journal of Finance 45, 321-349.

Harris, Milton, and Artur Raviv, 1991, The theory of capital structure, Journal of Finance 46, 297 355.

Hart, Oliver D., 1993, Theories of optimal capital structure: A managerial discretion perspective, in Margaret M. Blair, ed.: The deal decade: What takeovers and leveraged buyouts mean for corporate governance (Brookings Institution, Washington, DC), 19-53.

Hart, Oliver D., and John Moore, 1990, A theory of corporate financial structure based on the seniority of claims, Working paper \#560 (Massachusetts Institute of Technology, Cambridge, MA).

Haugen, R., and Lemma Senbet, 1981, Resolving the agency problems of external capital through options, Journal of Finance 36, 629-648. 
Jensen, Michael C., 1986, Agency costs of free cash flow, corporate finance and takeovers, American Economic Review 76, 323-339.

Jensen, Michael C., 1993, The modern industrial revolution, exit, and the failure of internal control systems, Journal of Finance 48, 831-880.

Jensen, Michael C., and William H. Meckling, 1976, Theory of the firm: Managerial behavior, agency costs, and capital structure, Journal of Financial Economics 3, 305-360.

Jensen, Michael C., and Kevin J. Murphy, 1990, Performance pay and top-management incentives, Journal of Political Economy 98, 225-264.

Jung, Kooyul, Yong-Cheol Kim, and René Stulz, 1996, Timing, investment opportunities, managerial discretion, and the security issue decision, Journal of Financial Economics 42, 159-186.

Lipton, Martin, and Jay W. Lorsch, 1992, A modest proposal for improved corporate governance, Business Lawyer 48, no. 1, 59-77.

MacKie-Mason, Jeffrey K., 1990, Do taxes affect corporate financing decisions? Journal of Finance 45, 1471-1493.

Mehran, Hamid, 1992, Executive incentive plans, corporate control, and capital structure, Journal of Financial and Quantitative Analysis 27, 539-560.

Mørck, Randall, Andrei Shleifer, and Robert Vishny, 1988, Management ownership and market valuation: An empirical analysis, Journal of Financial Economics 20, 293-315.

Novaes, Walter, and Luigi Zingales, 1995, Capital structure choice when managers are in control: Entrenchment versus efficiency, unpublished working paper (Graduate School of Business, University of Chicago, Chicago, IL).

Ofek, Eli, 1994, Efficiency gains in unsuccessful management buyouts, Journal of Finance 49, 637654.

Opler, Tim, and Sheridan Titman, 1996, The debt-equity choice: An analysis of issuing firms, Journal of Finance, forthcoming.

Saffieddine, Assem, and Sheridan Titman, 1996, Debt and corporate performance: Evidence from unsuccessful takeovers, unpublished working paper (Broad Graduate School of Management, Michigan State University, East Lansing, MI).

Smith, Clifford W., and Ross L. Watts, 1982, Incentive and tax effects of U.S. executive compensation plans, Australian Management Journal 7, 139-157. 
Smith, Clifford W., and Ross L. Watts, 1992, The investment opportunity set and corporate financing, dividend, and compensation policies, Journal of Financial Economics 32, 263-292.

Stulz, René, 1988, Managerial control of voting rights: Financing policies and the market for corporate control, Journal of Financial Economics 20, 25-54.

Stulz, René, 1990, Managerial discretion and optimal financing policies, Journal of Financial Economics 26, 3-27.

Titman, Sheridan, and Roberto Wessels, 1988, The determinants of capital structure choice, Journal of Finance 43, 1-19.

Weisbach, Michael, 1988, Outside directors and CEO turnover, Journal of Financial Economics 20, 431-460.

Williamson, Oliver, 1988, Corporate finance and corporate governance, Journal of Finance 43, 567591.

Yermack, David, 1995, Do Corporations award CEO stock options effectively? Journal of Financial Economics 39, 237-270.

Yermack, David, 1996, Higher market valuation of companies with a small board of directors, Journal of Financial Economics 40, 185-211.

Zwiebel, Jeffrey, 1994, Dynamic capital structure under managerial entrenchment, unpublished working paper (Graduate School of Business, Stanford University, Palo Alto, CA). 


\section{FIGURE 1}

\section{Changes in leverage after shocks to managerial security}

Changes in leverage around events that represent shocks to managerial security. The figure shows mean levels of the ratio of (total debt / total assets) for sample firms that experience one of three types of shocks: an unsuccessful tender offer, the addition of a 5\% stockholder to the board of directors, or the departure of the company's prior CEO under circumstances that appeared involuntary (the CEO was age 62 or less and did not remain on the board of directors). Observations represent subsets of a sample of 2,196 observations for 409 firms in the 1984-91 period. We include in this figure only those observations with data available three years before and after the event year.

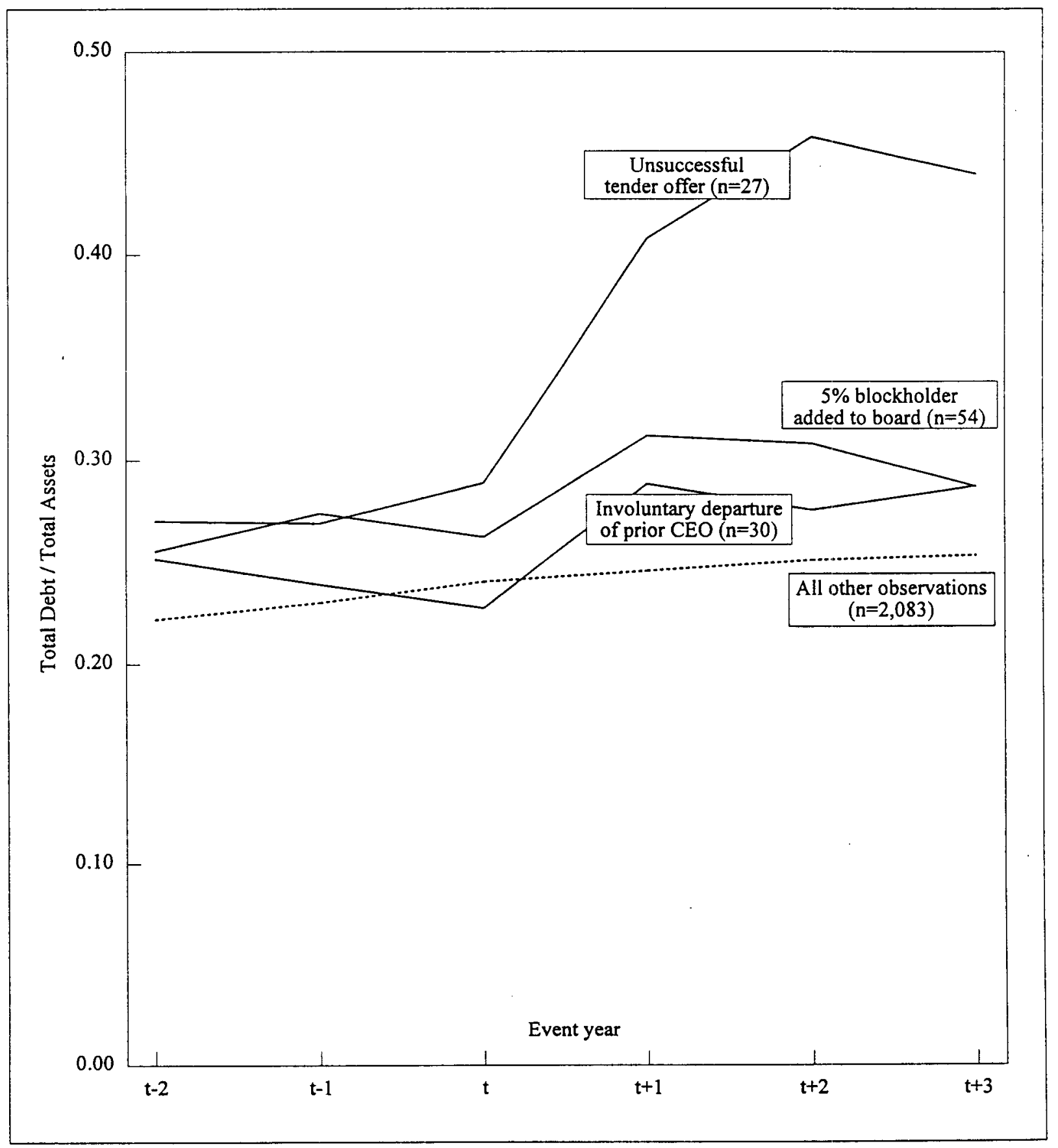




\section{TABLE I}

\section{Variables for analysis of capital structure levels}

Definitions and descriptive statistics for variables used in analysis of capital strucutre levels. The sample consists of 3,085 observations for 434 companies in the $1984-91$ period. Financial statetment variables were obtained from Compustat, with balance sheet items defined as of the end of each fiscal year. Corporate governance and stock ownership variables were obtained from proxy statements generally filed by each company during the third or fourth month of its fiscal year.

$\begin{array}{llcc}\text { Dependent variables } & \text { Definition } & \text { Mean } & \text { Std. dev } \\ \text { Leverage (book value) } & \begin{array}{l}\text { total debt (book value) } \\ \text { / total assets }\end{array} & 0.247 & 0.169 \\ & & & \\ \text { Leverage (market value) } & \text { total debt (book value) } & 0.265 & 0.202 \\ & \text { /(total debt (book value) + equity (market value)) }\end{array}$

\begin{tabular}{|c|c|c|c|c|c|}
\hline \multirow{3}{*}{$\begin{array}{l}\text { Explanatory variables } \\
\text { CEO stock ownership }\end{array}$} & \multicolumn{5}{|c|}{$\begin{array}{c}\text { Correlation with } \\
\text { Leverage }\end{array}$} \\
\hline & Definition & Mean & Std. dev. & (book vall & \\
\hline & $\begin{array}{l}\text { shares owned directly } \\
\text { / shares outstanding }\end{array}$ & 0.027 & 0.079 & 0.009 & \\
\hline CEO option holdings & $\begin{array}{l}\text { exercisable options held } \\
\text { / shares outstanding }\end{array}$ & 0.0017 & 0.0052 & 0.098 & $* * *$ \\
\hline $\begin{array}{l}\text { Presence of at least one } 5 \% \text { blockholder } \\
\text { (indicator variable) }\end{array}$ & $\begin{array}{l}=1 \text { if company has at least one } \\
5 \% \text { stockholder (excluding ESOPs) }\end{array}$ & 0.517 & 0.500 & 0.041 & ** \\
\hline CEO tenure & $\log$ (years in CEO position) & 1.843 & 0.969 & -0.047 & $* *$ \\
\hline Board composition & $\%$ of outside directors & 0.539 & 0.192 & 0.061 & $* * *$ \\
\hline Board size & $\log$ (number of directors) & 2.466 & 0.290 & 0.081 & $* * *$ \\
\hline Return on assets & $\begin{array}{l}\text { earnings before interest, taxes } \\
\text { and depreciation / total assets }\end{array}$ & 0.188 & 0.098 & -0.246 & $* * *$ \\
\hline Non-interest tax shields & $\begin{array}{l}\text { investment tax credits } \\
\text { / total assets }\end{array}$ & 0.0014 & 0.0065 & 0.037 & ** \\
\hline Asset collateral value & $\begin{array}{l}\text { (net property, plant \& equipment } \\
+ \text { inventory) / total assets }\end{array}$ & 0.575 & 0.184 & 0.032 & * \\
\hline Company size & $\log$ (total assets) & 7.766 & 1.139 & 0.262 & $* * *$ \\
\hline Asset uniqueness (1) & $\begin{array}{l}\text { research \& development expense } \\
\text { / sales }\end{array}$ & 0.020 & 0.038 & -0.207 & $* * *$ \\
\hline Asset uniqueness (2) & $\begin{array}{l}\text { selling, general \& admin. expense } \\
\text { / sales }\end{array}$ & 0.156 & 0.138 & -0.196 & $* * *$ \\
\hline
\end{tabular}

Correlations significant at the 10 percent $\left({ }^{*}\right), 5$ percent $\left({ }^{* *}\right)$ and 1 percent $\left({ }^{* * *}\right)$ levels. 


\section{TABLE II}

\section{Regression coefficient estimates: Determinants of capital structure levels}

OLS regression coefficients for models of capital structure leveis. The sample consists of 3,085 observations for 434 companies in the 1984-91 period. Variable definitions appear in Table I. T-statistics appear in parentheses below each coefficient estimate. For each of the two specifications of the dependent variable, the table shows ordinary least squares estimates as well as betweenfirm and within-firm estimates calculated using standard panel data techniques.

\begin{tabular}{|c|c|c|c|c|c|c|}
\hline \multirow[t]{2}{*}{ Dependent variable: } & \multicolumn{3}{|c|}{ Leverage (book value) } & \multicolumn{3}{|c|}{ Leverage (market value) } \\
\hline & $\frac{\text { OLS }}{\text { Estimates }}$ & $\frac{\text { Between }}{\text { Estimates }}$ & $\underset{\text { Estimates }}{\text { Within }}$ & $\begin{array}{c}\text { OLS } \\
\text { Estimates }\end{array}$ & $\begin{array}{l}\text { Between } \\
\text { Estimates }\end{array}$ & $\underset{\text { Estimates }}{\text { Within }}$ \\
\hline $\begin{array}{l}\text { CEO direct stock ownership } \\
\text { (\% of common shares) }\end{array}$ & $\begin{array}{l}0.156 * * \\
(3.84)\end{array}$ & $\begin{array}{l}0.153 \\
(1.63)\end{array}$ & $\begin{array}{l}0.143 \\
(1.62)\end{array}$ & $\begin{array}{l}0.258 * * * \\
(6.11)\end{array}$ & $\begin{array}{l}0.217 \\
(2.21)\end{array}$ & $\begin{array}{l}0.249 * * * \\
(2.89)\end{array}$ \\
\hline $\begin{array}{l}\text { CEO vested option holdings } \\
\text { (\% of common shares) }\end{array}$ & $\begin{array}{l}2.883^{* * *} \\
(5.32)\end{array}$ & $\begin{array}{l}3.106 * * \\
(2.13)\end{array}$ & $\begin{array}{l}0.804 \\
(1.22)\end{array}$ & $\begin{array}{l}3.382 * * * \\
(5.99)\end{array}$ & $\begin{array}{l}3.100 \cdots \\
(2.03)\end{array}$ & $\begin{array}{l}1.410 * * \\
(2.18)\end{array}$ \\
\hline $\begin{array}{l}\text { Presence of at least one } 5 \% \text { blockholder } \\
\text { (indicator variable) }\end{array}$ & $\begin{array}{l}0.018^{* * *} \\
(3.14)\end{array}$ & $\begin{array}{l}0.017 \\
(0.98)\end{array}$ & $\begin{array}{l}0.009 \\
(1.50)\end{array}$ & $\begin{array}{l}0.033 \cdots * \\
(5.57)\end{array}$ & $\begin{array}{l}0.043 * * \\
(2.41)\end{array}$ & $\begin{array}{l}0.003 \\
(0.57)\end{array}$ \\
\hline $\begin{array}{l}\text { CEO tenure } \\
\qquad(\log (\text { years in office }))\end{array}$ & $\begin{array}{r}-0.005 \\
(1.54)\end{array}$ & $\begin{array}{l}-0.011 \\
(1.14)\end{array}$ & $\begin{array}{r}-0.001 \\
(0.40)\end{array}$ & $\begin{array}{l}-0.011^{* * *} \\
(3.51)^{*}\end{array}$ & $\begin{array}{l}-0.017 \\
(1.77)\end{array}$ & $\begin{array}{l}-0.008 \cdots * \\
(3.02)\end{array}$ \\
\hline $\begin{array}{l}\text { Board composition } \\
\text { ( } \% \text { outside directors) }\end{array}$ & $\begin{array}{l}0.006 \\
(0.41)\end{array}$ & $\begin{array}{l}-0.028 \\
(0.71)\end{array}$ & $\begin{array}{l}0.058 * * \\
(1.98)\end{array}$ & $\begin{array}{l}0.035 * \\
(2.11)\end{array}$ & $\begin{array}{l}-0.010 \\
(0.25)\end{array}$ & $\begin{array}{l}0.077^{* * *} \\
(2.69)\end{array}$ \\
\hline $\begin{array}{l}\text { Board size } \\
\qquad(\log \text { (number of directors)) }\end{array}$ & $\begin{array}{l}-0.036^{* * *} \\
(2.96)\end{array}$ & $\begin{array}{r}-0.033 \\
(1.08)\end{array}$ & $\begin{array}{l}-0.051^{* * *} \\
(2.72)\end{array}$ & $\begin{array}{l}-0.027 * * \\
(2.10)\end{array}$ & $\begin{array}{l}-0.024 \\
(0.73)\end{array}$ & $\begin{array}{l}-0.062 * * * \\
(3.41)\end{array}$ \\
\hline $\begin{array}{l}\text { Excess compensation } \\
\quad \text { (actual - predicted log (salary+bonus)) }\end{array}$ & $\begin{array}{l}0.001 \\
(0.15)\end{array}$ & $\begin{array}{l}0.005 \\
(0.33)\end{array}$ & $\begin{array}{l}-0.021 * \cdots * \\
(2.66)\end{array}$ & $\begin{array}{r}-0.004 \\
(0.65)\end{array}$ & $\begin{array}{l}0.0001 \\
(0.00)\end{array}$ & $\begin{array}{l}-0.036 \cdots * \\
(4.68)\end{array}$ \\
\hline $\begin{array}{l}\text { Return on assets } \\
\text { (EBDIT / total assets) }\end{array}$ & $\begin{array}{l}-0.346 * * * \\
(10.95)\end{array}$ & $\begin{array}{l}-0.347^{* * *} \\
(3.83)\end{array}$ & $\begin{array}{l}-0.230^{* * *} \\
(6.75)\end{array}$ & $\begin{array}{l}-0.805 \cdots * * \\
(24.42)\end{array}$ & $\begin{array}{l}-0.953 \cdots * * \\
(9.98)\end{array}$ & $\begin{array}{l}-0.489 * * * \\
(14.65)\end{array}$ \\
\hline $\begin{array}{l}\text { Non-interest tax shields } \\
\quad \text { (investment tax credits / total assets) }\end{array}$ & $\begin{array}{l}-3.750 * * * \\
(6.72)\end{array}$ & $\begin{array}{l}-3.564 * * \\
(2.24)\end{array}$ & $\begin{array}{l}-0.734 \\
(1.05)\end{array}$ & $\begin{array}{l}-1.112 \\
(1.92)\end{array}$ & $\begin{array}{r}-0.650 \\
(0.39)\end{array}$ & $\begin{array}{l}0.925 \\
(1.35)\end{array}$ \\
\hline $\begin{array}{l}\text { Asset collateral value } \\
\quad(\text { (net PPE + inventory) / total assets })\end{array}$ & $\begin{array}{l}0.008 \\
(0.43)\end{array}$ & $\begin{array}{l}0.050 \\
(1.04)\end{array}$ & $\begin{array}{l}-0.146 * * * \\
(4.92)\end{array}$ & $\begin{array}{l}-0.021 \\
(1.03)\end{array}$ & $\begin{array}{l}0.009 \\
(0.18)\end{array}$ & $\begin{array}{l}-0.143 * * * \\
(4.95)\end{array}$ \\
\hline $\begin{array}{l}\text { Company size } \\
\text { (log of total assets) }\end{array}$ & $\begin{array}{l}0.036^{* * *} \\
(10.01)\end{array}$ & $\begin{array}{l}0.034 \text { *** } \\
(3.69)\end{array}$ & $\begin{array}{l}0.066 * * * \\
(8.59)\end{array}$ & $\begin{array}{l}0.047 \\
(12.57)\end{array}$ & $\begin{array}{l}0.039 * * * \\
(4.02)\end{array}$ & $\begin{array}{l}0.130 * * \\
(17.14)\end{array}$ \\
\hline $\begin{array}{l}\text { Asset uniqueness } \\
\text { (R\&D expense / sales) }\end{array}$ & $\begin{array}{l}-0.632 \cdots * \\
(6.85)\end{array}$ & $\begin{array}{l}-0.726 * * * \\
(3.10)\end{array}$ & $\begin{array}{l}-0.296 * \\
(1.72)\end{array}$ & $\begin{array}{l}-0.825 * * * * \\
(8.59)\end{array}$ & $\begin{array}{l}-0.860 * * * \\
(3.50)\end{array}$ & $\begin{array}{l}-0.364 * * \\
(2.16)\end{array}$ \\
\hline $\begin{array}{l}\text { Asset uniqueness } \\
\text { (SGA expense / sales) }\end{array}$ & $\begin{array}{l}-0.086 * * * \\
(3.32)\end{array}$ & $\begin{array}{r}-0.087 \\
(1.30)\end{array}$ & $\begin{array}{l}-0.074 * * \\
(2.02)\end{array}$ & $\begin{array}{l}-0.164 * * * 1 \times \\
(6.05)\end{array}$ & $\begin{array}{l}-0.165 * * \\
(2.34)\end{array}$ & $\begin{array}{l}-0.134^{* * *} \\
(3.73)\end{array}$ \\
\hline $\begin{array}{l}\text { Industry indicator variables (2-digit SIC) } \\
\text { Year indicator variables } \\
\text { Observations } \\
\text { R-squared } \\
\text { F-statistic } \\
\text { P-value }\end{array}$ & $\begin{array}{c}\text { Yes } \\
\text { Yes } \\
3,085 \\
0.293 \\
18.38 \\
0.00\end{array}$ & $\begin{array}{c}\text { Yes } \\
\text { Yes } \\
434 \\
0.419 \\
3.87 \\
0.00\end{array}$ & $\begin{array}{c}\text { No } \\
\text { Yes } \\
3,085 \\
0.124 \\
0.84 \\
0.99\end{array}$ & $\begin{array}{c}\text { Yes } \\
\text { Yes } \\
3,083 \\
0.464 \\
38.37 \\
0.00\end{array}$ & $\begin{array}{c}\text { Yes } \\
\text { Yes } \\
434 \\
0.576 \\
7.29 \\
0.00\end{array}$ & $\begin{array}{c}\text { No } \\
\text { Yes } \\
3,083 \\
0.251 \\
1.98 \\
0.00\end{array}$ \\
\hline
\end{tabular}




\section{TABLE III}

\section{Variables for analysis of capital structure changes}

Definitions and descriptive statistics for variables used in analysis of capital strucutre changes, in addition to those variables listed in Table I. The sample consists of 2,196 observations for 409 companies in the 1984-91 period. Financial statement variables were obtained from Compustat. Corporate governance and stock ownership variables were obtained from proxy statements generally filed by each company during the third or fourth month of its fiscal year. Stock return variables were obtained from CRSP.

\begin{tabular}{|c|c|c|c|}
\hline $\begin{array}{l}\text { Dependent variables } \\
\text { Net debt issued }\end{array}$ & $\begin{array}{l}\text { Definition } \\
\text { (debt issued - debt retired) } \\
\text { / total assets }\end{array}$ & $\begin{array}{l}\text { Mean } \\
0.022\end{array}$ & $\frac{\text { Std. dev. }}{0.132}$ \\
\hline Equity issued & $\begin{array}{l}\text { new equity issued } \\
/ \text { total assets }\end{array}$ & 0.015 & 0.055 \\
\hline Equity repurchased & $\begin{array}{l}\text { equity repurchased } \\
\text { / total assets }\end{array}$ & 0.020 & 0.046 \\
\hline Change in leverage & $\begin{array}{l}\text { (net debt issued - equity issued) } \\
\text { / total assets }\end{array}$ & 0.027 & 0.150 \\
\hline $\begin{array}{l}\text { Explanatory variables } \\
\text { Unsuccessful tender offer } \\
\text { (indicator variable) }\end{array}$ & $\begin{array}{l}\text { Definition } \\
=1 \text { if tender offer made for company } \\
\text { during year without control change }\end{array}$ & $\frac{\text { Mean }}{0.013}$ & $\frac{\text { Std. dev }}{0.114}$ \\
\hline $\begin{array}{l}\text { First year of new CEO } \\
\text { (indicator variable) }\end{array}$ & $\begin{array}{l}=1 \text { if } C E O \text { is serving in first fiscal year } \\
\text { of six months or more }\end{array}$ & 0.097 & 0.296 \\
\hline $\begin{array}{l}\text { First year of new CEO following } \\
\text { involuntary departure of predecessor } \\
\text { (indicator variable) }\end{array}$ & $\begin{array}{l}=1 \text { if new } C E O \text { indicator }=1 \text { and prior } \\
\text { CEO was age } 62 \text { or less and did not } \\
\text { remain as member of board of directors }\end{array}$ & 0.015 & 0.121 \\
\hline $\begin{array}{l}\text { Addition of } 5 \% \text { blockholder to } \\
\text { board of directors (indicator variable) }\end{array}$ & $\begin{array}{l}=1 \text { if number of } 5 \% \text { stockholders on } \\
\text { board of directors increases }\end{array}$ & 0.029 & 0.168 \\
\hline Market-to-book ratio (start of year) & $\begin{array}{l}\text { (equity (market value - book value) } \\
+ \text { total assets) / total assets }\end{array}$ & 1.294 & 0.919 \\
\hline Stock return & stock retum during prior fiscal year & 0.193 & 0.361 \\
\hline Tax status (start of year) & $\begin{array}{l}\text { net operating loss carry-forward } \\
\text { / total assets }\end{array}$ & 0.015 & 0.074 \\
\hline
\end{tabular}




\section{TABLE IV}

\section{Regression coefficient estimates: Determinants of capital structure changes}

OLS regression coefficients for models of capital structure changes. The total sample consists of 2,196 observations for 409 companies in the 1984-91 period. Variable definitions appear in Tables I and III. T-statistics appear in parentheses below each coefficient estimate.

Year following unsuccessful tender offer

First year of new CEO

First year of new CEO following involuntary departure of predecessor

Year following addition of 5\% blockholder to board of directors

Change in CEO stock ownership ( $\%$ of common shares)

Change in CEO exercisable option holdings (\% of common shares)

Change in board composition (\% outside directors)

Change in board size

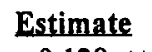
$0.129^{* * *}$ (4.73)

0.007

$(0.67)$
Estimate

Estimate

$0.088 * * *$

(3.27)

$\begin{array}{lllll} & & 0.088 * * * & & 0.071 * * \\ & & (3.27) & & (2.35) \\ & & & & \\ & & & 0.069 * * * & 0.071 * * * \\ & & & (3.29) & (3.16) \\ -0.066 & -0.071 & -0.067 & -0.130 & -0.117 \\ (0.69) & (0.76) & (0.70) & (1.24) & (1.10) \\ & & & & \\ 4.324 * * * & 4.153 * * * & 3.947 * * * & 4.460 * * * & 4.346 * * * \\ (4.91) & (4.84) & (4.47) & (4.85) & (4.62) \\ & & & & \\ 0.056 & 0.062 & 0.049 & 0.053 & 0.034 \\ (1.10) & (1.24) & (0.92) & (0.92) & (0.55) \\ & & & & \\ -0.003 & -0.003 & -0.003 & -0.003 & -0.002 \\ (1.18) & (1.35) & (1.13) & (1.07) & (0.91)\end{array}$

Estimate

Estimate

$0.121^{* * *}$

(3.91)

Table continued on next page 


\section{TABLE IV continued}

\section{Regression coefficient estimates: Determinants of capital structure changes}

OLS regression coefficients for models of capital structure changes. The total sample consists of 2,196 observations for 409 companies in the 1984-91 period. Variable definitions appear in Tables I and III. T-statistics appear in parentheses below each coefficient estimate.

Dependent variable: (net debt issued - equity issued + equity repurchased) / total assets

\begin{tabular}{|c|c|c|c|c|c|}
\hline $\begin{array}{l}\text { Retum on assets during prior year } \\
\text { (EBDIT / total assets) }\end{array}$ & $\begin{array}{l}0.059 \\
(1.33)\end{array}$ & $\begin{array}{l}0.064 \\
(1.47)\end{array}$ & $\begin{array}{l}0.073 \\
(1.59)\end{array}$ & $\begin{array}{l}0.083 \\
(1.71)\end{array}$ & $\begin{array}{l}0.091 \\
(1.78)\end{array}$ \\
\hline Stock return during prior year & $\begin{array}{l}-0.002 \\
(0.25)\end{array}$ & $\begin{array}{l}-0.003 \\
(0.29)\end{array}$ & $\begin{array}{l}-0.004 \\
(0.40)\end{array}$ & $\begin{array}{l}-0.008 \\
(0.72)\end{array}$ & $\begin{array}{l}-0.011 \\
(0: 89)\end{array}$ \\
\hline $\begin{array}{l}\text { Leverage (book value) at start of year } \\
\text { (total debt / total assets) }\end{array}$ & $\begin{array}{l}-0.127^{* * *} \\
(6.32)\end{array}$ & $\begin{array}{l}-0.124 * * * \\
(6.33)\end{array}$ & $\begin{array}{l}-0.108 * * * \\
(5.03)\end{array}$ & $\begin{array}{l}-0.107^{* * *} \\
(4.70)\end{array}$ & $\begin{array}{l}-0.089 * * * \\
(3.54)\end{array}$ \\
\hline Market-to-book ratio (start of year) & $\begin{array}{l}0.013 * * * \\
(2.65)\end{array}$ & $\begin{array}{l}0.012 * * * \\
(2.45)\end{array}$ & $\begin{array}{l}0.012 * * * \\
(2.44)\end{array}$ & $\begin{array}{l}0.015^{* * *} \\
(2.53)\end{array}$ & $\begin{array}{l}0.017^{* * *} \\
(2.71)\end{array}$ \\
\hline $\begin{array}{l}\text { Tax status } \\
\text { (net op. loss carry-fwd. / total assets) }\end{array}$ & $\begin{array}{l}-0.075 * \\
(1.71)\end{array}$ & $\begin{array}{l}-0.075 \\
(1.76)\end{array}$ & $\begin{array}{l}-0.072 \\
(1.62)\end{array}$ & $\begin{array}{l}-0.097 \\
(1.95)\end{array}$ & $\begin{array}{l}-0.090 \\
(1.73)\end{array}$ \\
\hline $\begin{array}{l}\text { Non-interest tax shields } \\
\quad \text { (investment tax credits / total assets) }\end{array}$ & $\begin{array}{l}-0.500 \\
(0.93)\end{array}$ & $\begin{array}{l}-0.462 \\
(0.88)\end{array}$ & $\begin{array}{l}-0.441 \\
(0.79)\end{array}$ & $\begin{array}{l}-0.403 \\
(0.71)\end{array}$ & $\begin{array}{l}-0.295 \\
(0.49)\end{array}$ \\
\hline $\begin{array}{l}\text { Asset collateral value } \\
\quad((\text { net PPE }+ \text { inventory }) / \text { total assets })\end{array}$ & $\begin{array}{r}-0.023 \\
(1.30)\end{array}$ & $\begin{array}{l}-0.026 \\
(1.52)\end{array}$ & $\begin{array}{l}-0.023 \\
(1.25)\end{array}$ & $\begin{array}{l}-0.029 \\
(1.46)\end{array}$ & $\begin{array}{l}-0.029 \\
(1.34)\end{array}$ \\
\hline $\begin{array}{l}\text { Company size } \\
\text { (log of total assets) }\end{array}$ & $\begin{array}{l}0.007^{* *} \\
(2.19)\end{array}$ & $\begin{array}{l}0.007 * * \\
(2.21)\end{array}$ & $\begin{array}{l}0.007 * * \\
(2.14)\end{array}$ & $\begin{array}{l}0.007 * * \\
(2.14)\end{array}$ & $\begin{array}{l}0.006 \\
(1.59)\end{array}$ \\
\hline $\begin{array}{l}\text { Asset uniqueness } \\
\text { (R\&D expense / sales) }\end{array}$ & $\begin{array}{l}-0.542 * * * \\
(5.36)\end{array}$ & $\begin{array}{l}-0.543 * * * \\
(5.50)\end{array}$ & $\begin{array}{l}-0.515^{* * *} \\
(4.84)\end{array}$ & $\begin{array}{l}-0.630 * * * \\
(5.39)\end{array}$ & $\begin{array}{l}-0.584^{* * *} \\
(4.65)\end{array}$ \\
\hline $\begin{array}{l}\text { Asset uniqueness } \\
\text { (SGA expense / sales) }\end{array}$ & $\begin{array}{l}0.0002 \\
(0.01)\end{array}$ & $\begin{array}{r}0.006 \\
(0.21)\end{array}$ & $\begin{array}{c}0.011 \\
(0.40)\end{array}$ & $\begin{array}{c}0.001 \\
(0.03)\end{array}$ & $\begin{array}{c}0.003 \\
(0.10)\end{array}$ \\
\hline $\begin{array}{l}\text { Year indicator variables } \\
\text { Observations } \\
\text { R-squared } \\
\text { F-statistic } \\
\text { P-value }\end{array}$ & $\begin{array}{l}\text { Yes } \\
2,196 \\
0.072 \\
8.05 \\
0.00\end{array}$ & $\begin{array}{l}\text { Yes } \\
2,191 \\
0.064 \\
7.11 \\
0.00\end{array}$ & $\begin{array}{l}\text { Yes } \\
2,008 \\
0.065 \\
6.55 \\
0.00\end{array}$ & $\begin{array}{l}\text { Yes } \\
1,854 \\
0.067 \\
6.62 \\
0.00\end{array}$ & $\begin{array}{c}\text { Yes } \\
1,695 \\
0.076 \\
6.24 \\
0.00\end{array}$ \\
\hline
\end{tabular}

Significant at 1 percent $\left({ }^{* *}\right), 5$ percent $(* *)$ and 10 percent $\left({ }^{*}\right)$ levels. 


\section{TABLE V \\ Regression coefficient estimates: Entrenchment variables and capital structure changes}

OLS regression coefficients for models of capital structure changes. The entire sample consists of 2,196 observations for 409 companies in the 1984-91 period. Variable definitions appear in Tables I and III. $\mathrm{T}$-statistics appear in parentheses below each coefficient estimate.

Each cell in the table represents the outcome for a separate OLS regression. The dependent variable for each regression appears at the top of each column. The explanatory variables for each regression include a measure of CEO entrenchment listed in the left column, as well as the entire set of control variables used in the models in Table IV.

\begin{tabular}{|c|c|c|c|}
\hline $\begin{array}{l}\text { Dependent variable : } \\
\text { Variables representing } \\
\text { shocks to managerial }\end{array}$ & $\begin{array}{c}\text { Net debt issued } \\
\text { (debt issued - debt retired) / } \\
\text { total assets }\end{array}$ & $\begin{array}{l}\text { New equity issued } \\
\text { new equity issued / } \\
\text { total assets }\end{array}$ & $\begin{array}{l}\text { Equity repurchased } \\
\text { equity repurchased / } \\
\text { total assets }\end{array}$ \\
\hline $\begin{array}{l}\text { Year following } \\
\text { unsuccessful tender offer }\end{array}$ & $\begin{array}{l}0.120 \quad * * * \\
(5.09)\end{array}$ & $\begin{array}{l}0.029 * * \\
(3.25)\end{array}$ & $\begin{array}{l}0.047 \quad * * * \\
(6.03)\end{array}$ \\
\hline First year of new CEO & $\begin{array}{r}-0.001 \\
(0.07)\end{array}$ & $\begin{array}{l}-0.0004 \\
(0.12)\end{array}$ & $\begin{array}{l}0.004 \\
(1.37)\end{array}$ \\
\hline $\begin{array}{l}\text { First year of new CEO } \\
\text { following involuntary } \\
\text { departure of predecessor }\end{array}$ & $\begin{array}{l}0.082^{* * *} \\
(3.46)\end{array}$ & $\begin{array}{l}-0.0004 \\
(0.04)\end{array}$ & $\begin{array}{l}0.015 \\
(1.80)\end{array}$ \\
\hline $\begin{array}{l}\text { Year following addition of } \\
5 \% \text { blockholder to board } \\
\text { of directors }\end{array}$ & $\begin{array}{l}0.100 \quad * * * \\
(5.55)\end{array}$ & $\begin{array}{l}0.009 \\
(1.21)\end{array}$ & $\begin{array}{c}-0.008 \\
(1.25)\end{array}$ \\
\hline
\end{tabular}

Significant at 1 percent $\left({ }^{* * *}\right), 5$ percent $\left({ }^{* *}\right)$ and 10 percent $(*)$ levels. 


\section{TABLE VI \\ OLS Regression Estimates: Changes in leverage as a function of prior leverage and shocks to CEO entrenchment}

OLS regression coefficients for models of changes in leverage. The change in leverage during the year is regressed against the leverage surplus at the start of the year. The leverage surplus is assumed to equal the residual from an OLS model of leverage levels similar to that in the first column of Table II. In addition, each model includes an interaction term between the leverage surplus and one of the variables used as a proxy for shocks to CEO entrenchment. The top half of the table shows estimates for the entire sample, while the lower half shows estimates for the subset of observations with actual leverage below predicted leverage. All models include the full range of control variables shown in Table IV, except that the level of leverage at the start of the year is excluded.

Dependent variable: (net debt issued - net equity issued) / total assets

\section{All observations}

Leverage surplus

$$
-0.166 * * *
$$

Estimate

(7.81)

Leverage surplus $\mathbf{x}$ indicator for unsuccessful tender offer events

Leverage surplus $\mathbf{x}$ indicator for first year of new CEO

Leverage surplus $\mathrm{x}$ indicator for new CEO (involuntary replacement)

Leverage surplus $\mathbf{x}$ indicator for addition of $5 \%$ blockholder to board

Number of observations

\section{Estimate \\ $-0.163 * * *$}

(7.66)

$-0.213$

(1.05)
$-0.219^{* * *}$

(3.96)

(5.81)

Estimate

$-0.132^{* * *}$

(5.82)

Estimate

$-0.124 * * *$

(5.15)
$-0.816^{* * *}$

(5.99)

$-0.886 * * *$

(6.58)

$\begin{array}{lllll}2,196 & 2,196 & 2,191 & 2,008 & 1,854\end{array}$

Firms with (total debt / total assets) below predicted level

Leverage surplus Estimate

$-0.139 * *$

Leverage surplus $\mathrm{x}$ indicator for unsuccessful tender offer events

Leverage surplus $\mathrm{x}$ indicator for CEO replacement

Leverage surplus $\mathrm{x}$ indicator for new CEO (involuntary replacement)

Leverage surplus $\mathbf{x}$ indicator for addition of $5 \%$ blockholder to board

Number of observations

Estimate
-0.123 **
$(2.15)$
-1.372 ***
$(4.14)$

$\begin{array}{ccc}\text { Estimate } & \text { Estimate } & \text { Estimate } \\ -0.085 & -0.071 & -0.081 * \\ (1.54) & (1.28) & (1.28)\end{array}$

\footnotetext{
Significant at 1 percent $\left({ }^{* * *}\right), 5$ percent $\left({ }^{* *}\right)$ and 10 percent $\left({ }^{*}\right)$ levels.
} 


\section{TABLE VII \\ Determinants of capital structure changes in low-leverage firms}

OLS regression coefficients for models of capital structure changes, with the analysis confined to firm-year observations with low levels of leverage. Coefficients are shown for variables used to indicate changes in managerial entrenchment, although the regressions are estimated using all explanatory variables shown in Table IV. T-statistics appear below each estimate in parentheses.

Estimates in the top half of the table are produced by analyzing observations with book value leverage below a predicted value, based upon fitted values from a regression similar to that shown in the first column of Table II. Estimates in the lower half of the table are produced by analyzing observations with book value leverage below a cutoff value of 0.35 . The entire sample includes 2,196 observations for 409 firms in 1984-91.

Dependent variable: (net debt issued - net equity issued) / total assets

Firms with (total debt / total assets) below predicted level

Year following

unsuccessful tender offer

Estimate

$0.210^{* * *}$

(5.61)

First year of new CEO

First year of new CEO following

involuntary departure of predecessor

Year following addition of 5\% blockholder

to board of directors

Number of observations

1,225
Estimate

$0.154^{* * *}$

(4.48)

$0.127^{* * *}$

1,223

1,120

1,024

Firms with (total debt / total assets) below 0.35

Year following

unsuccessful tender offer

Estimate

$0.184 * * *$

(5.73)

First year of new CEO

First year of new CEO following

involuntary departure of predecessor

Year following addition of 5\% blockholder to board of directors

Number of observations

Estimate

Estimate

$0.019 *$

Significant at 1 percent $\left({ }^{* * *}\right), 5$ percent $\left({ }^{* *}\right)$ and 10 percent $\left({ }^{*}\right)$ levels.

$0.120^{* * *}$

(4.23)

$0.081 * * *$

(3.14)

1,477 